Moon-Bum Kim, https://orcid.org/0000-0001-8801-1369

Hyang-Suk You, https://orcid.org/0000-0002-1697-397X

\section{REFERENCES}

1. Begovic N, Simic R, Vlahovic A, Kravljanac D, Djuricic S, Mijovic T. Cervical chondrocutaneous branchial remnants-report of 17 cases. Int J Pediatr Otorhinolaryngol 2014;78: 1961-1964.

2. Atlan G, Egerszegi EP, Brochu P, Caouette-Laberge L,
Bortoluzzi P. Cervical chrondrocutaneous branchial remnants. Plast Reconstr Surg 1997; 100:32-39.

3. Choi HJ, Lee JC, Kim JH. Cervical branchial cartilaginous remnant. J Craniofac Surg 2012;23:611-613.

4. Feito J, Ramos-García JL, Gago Á, Cobo JL, García-Suárez $O$, Junquera LM, et al. Pacinian corpuscles in a cervical chondrocutaneous remnant: a case report and update of pacinian corpuscles. Am J Dermatopathol 2016;38:231-235.

5. Tamir S, Nidal M, Constantin R, Perez R, Sichel JY. Bilateral cervical chondrocutaneous branchial remnants. Int J Pediatr Otorhinolaryngol Extra 2008;3:117-119.

\title{
Pirfenidone-Induced Lichenoid Drug Eruption in a Patient with Idiopathic Lung Fibrosis
}

\author{
In Jae Jeong, Hee Jung Lee, Moon Soo Yoon, Dong Hyun Kim \\ Department of Dermatology, CHA Bundang Medical Center, CHA University School of Medicine, Seongnam, Korea
}

\section{Dear Editor:}

A 75-year-old woman presented with generalized erythematous pruritic patches and papules on the face, neck and both extremities which occurred 2 months ago. The patient has developed Idiopathic pulmonary fibrosis (IPF) for 10 years and she was treated with pirfenidone 5 months ago with good tolerability. No adverse effect was reported during the first 3 months of administration, and the dose of pirfenidone was gradually increased from $600 \mathrm{mg} /$ day to $1,200 \mathrm{mg} /$ day for the symptom control. Skin rash initially developed in the sun exposed areas, but gradually spread to the whole body. Punch biopsy was performed on the dorsum of right hand (Fig. 1). We received the patient's consent form about publishing all photographic materials. Histopathology revealed lichenoid interface dermatitis, focal parakeratosis, and necrotic keratinocytes, which was consistent with lichenoid drug eruption (Fig. 2 ). The patient was initially treated with oral and topical steroid, but oral steroid was discontinued due to recurrent infection. Respiratory physician reduced the dose of pirfenidone to $600 \mathrm{mg} /$ day. After the dose reduction, symptoms have been controlled by topical steroids.

IPF is a progressive, fibrotic lung disease with poor prognosis. Median survival is 3 5 years without effective therapy ${ }^{1}$. Pirfenidone is an oral antifibrotic agent which inhibits tumor necrosis factor- $\alpha$ and transforming growth factor- $\beta$ with therapeutic effect for IPF. The primary treatment-related adverse events associated with pirfenidone are gastrointestinal upset, skin eruption. The skin eruption associated with pirfenidone has been reported in several cases related to photosensitivity, but no lichenoid drug eruption has been reported ${ }^{2}$.

\section{Received December 19, 2017, Revised January 12, 2018, Accepted for publication February 2, 2018}

Corresponding author: Dong Hyun Kim, Department of Dermatology, CHA Bundang Medical Center, CHA University School of Medicine, 59 Yatap-ro, Bundang-gu, Seongnam 13496, Korea. Tel: 82-31-780-5240, Fax: 82-31-780-5247, E-mail: terios92@hanmail.net ORCID: https://orcid.org/0000-0003-3394-2400

This is an Open Access article distributed under the terms of the Creative Commons Attribution Non-Commercial License (http://creativecommons.org/ licenses/by-nc/4.0) which permits unrestricted non-commercial use, distribution, and reproduction in any medium, provided the original work is properly cited.

Copyright (C) The Korean Dermatological Association and The Korean Society for Investigative Dermatology 

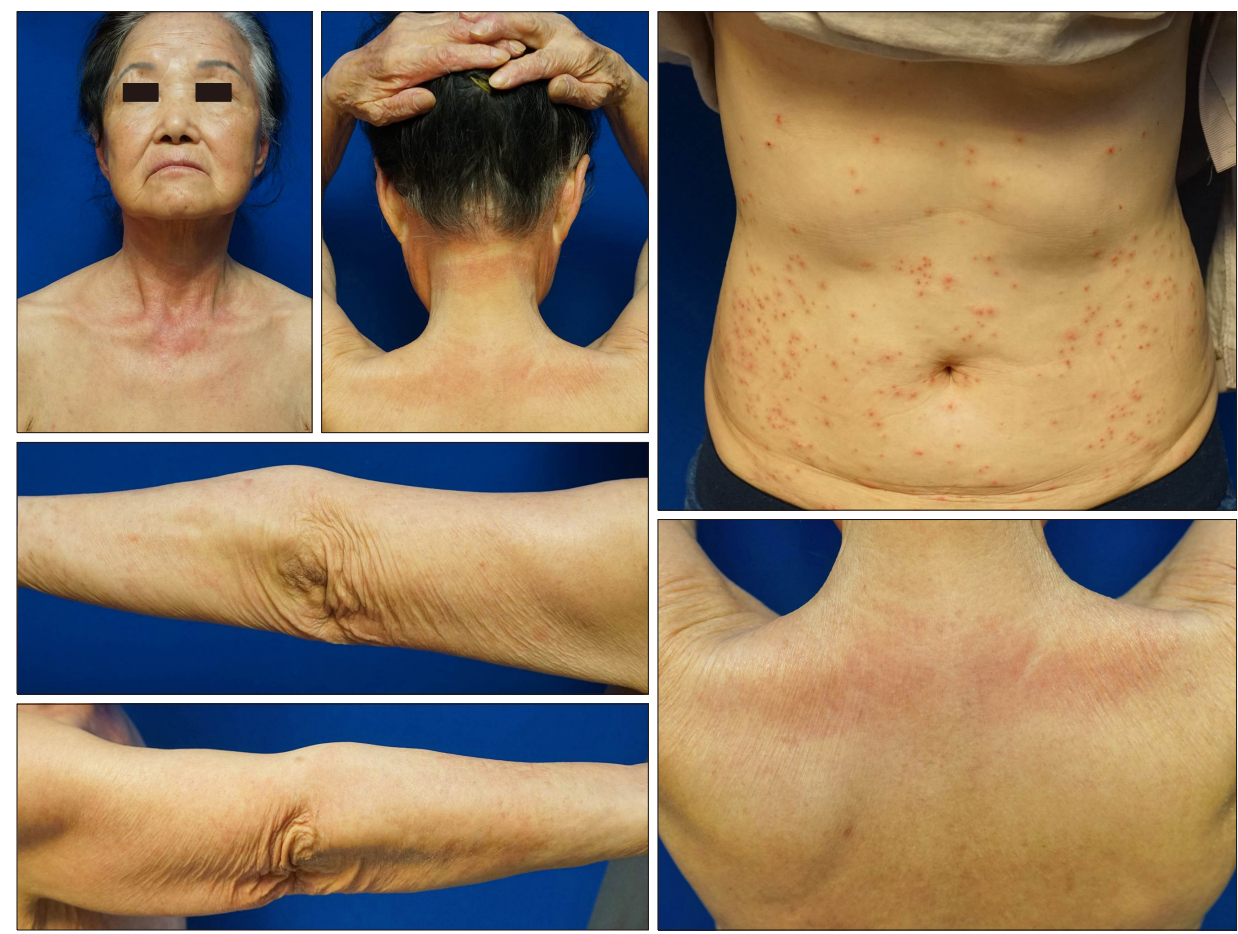

Fig. 1. Symmetrically distributed, multiple erythematous patches and papules with focal desquamation on the whole body.
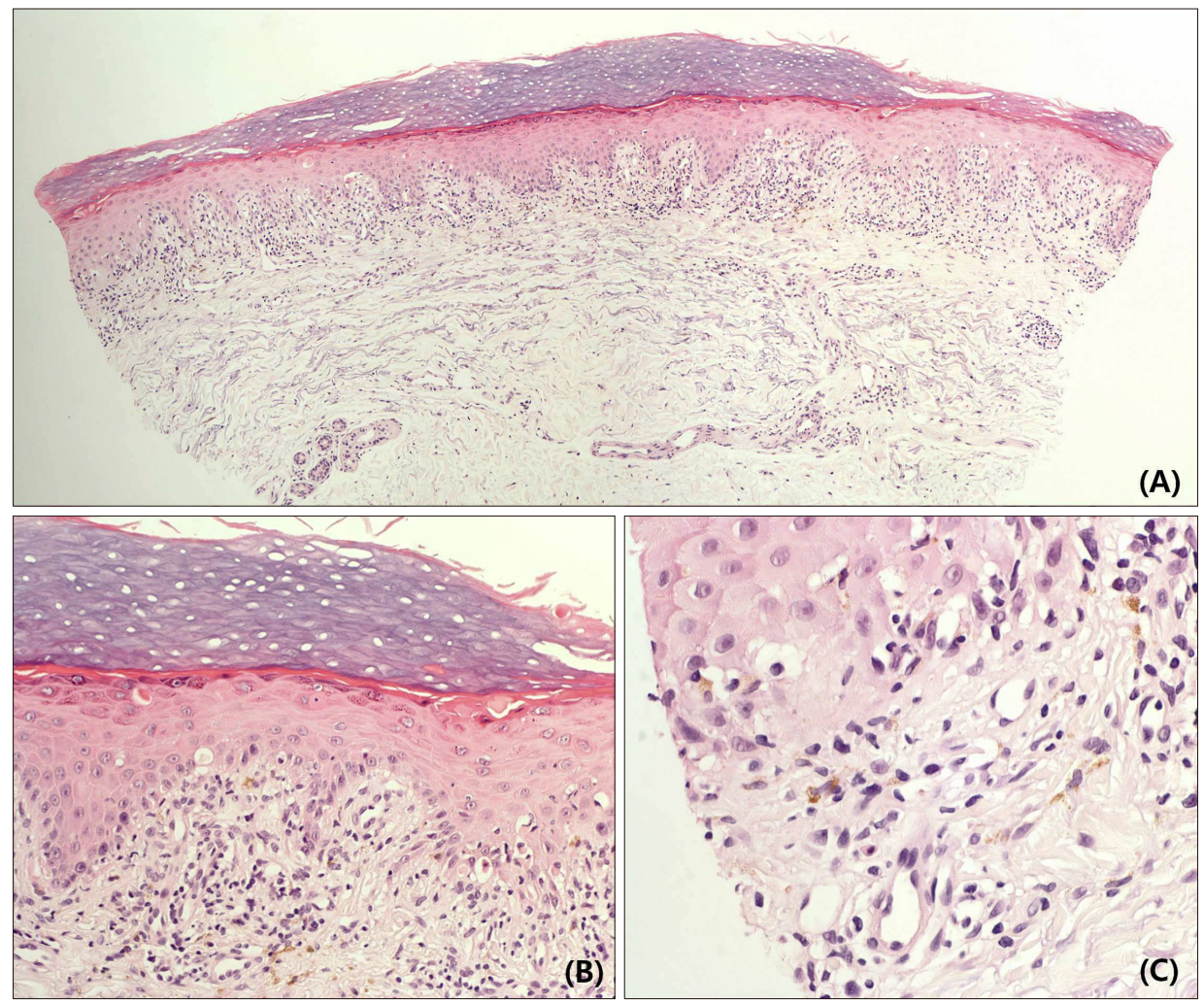

Fig. 2. (A) Hyperkeratosis and upper-dermal cellular infiltration obscures the epidermo-dermal junction. In mid to deep dermis, inflammatory cells infiltrate around vessels $(\mathrm{H} \& \mathrm{E}, \quad \times 40)$. (B, C) Necrotizing keratinocytes in the epidermis. Note the melanophages and lymphocytes in the cellular infiltrates $(\mathrm{H} \& \mathrm{E}: \mathrm{B}, \times 200 ; \mathrm{C}, \times 400)$.

Lichenoid drug eruption is a relatively rare form that accounts for less than $1 \%$ of drug related rash. Clinical and histopathologic findings are similar to those of idiopathic lichen planus, and there is no clear distinction between them. Lichenoid drug eruption occurs symmetrically in a wide area of the trunk, mucosa and nail involvement are rare, and Wickham stria is not observed. Histologically eosinophils and plasma cells are infiltrated upper dermis ${ }^{3}$. 
Drug eruption is generally known as the immunological mechanism associated with $\mathrm{T}$ cell response. However, pirfenidone seems to be involved in other mechanisms because the symptoms worsen due to the increased dose. First, there is a possibility that the occurrence of reactive oxygen species (ROS) due to phototoxic damage. In murine, as the dose of pirfenidone increased, the level of ROS increased during sun exposure, and it was possible that the $T$ cell was activated by a mechanism associated with an increase in the incidence of $\mathrm{ROS}^{4}$. Second, there is a possibility that pirfenidone is associated with the inhibition of TNF- $\alpha$. There are many reports of the lichenoid disease when TNF- $\alpha$ inhibitors are used. There is evidence that keratinocyte antigen expression and cytokine production may be an early event of lesion formation by keratinocyte apoptosis induced by antigen-specific CD8 + cytotoxic T cells ${ }^{5}$. Further studies are needed to determine the exact pathogenesis.

Herein, we describe a patient with IPF who presented with lichenoid drug eruption after initiation of pirfenidone therapy. Although pirfenidone is a key drug for the treatment of idiopathic pulmonary fibrosis, clinicians should be aware of the high prevalence of pirfenidone related drug eruption.

\section{CONFLICT OF INTEREST}

The authors have nothing to disclose.

\section{ORCID}

In Jae Jeong, https://orcid.org/0000-0001-9948-2318

Hee Jung Lee, https://orcid.org/0000-0001-9140-9677

Moon Soo Yoon, https://orcid.org/0000-0002-7470-6802

Dong Hyun Kim, https://orcid.org/0000-0003-3394-2400

\section{REFERENCES}

1. Noble PW, Albera C, Bradford WZ, Costabel U, Glassberg MK, Kardatzke D, et al. Pirfenidone in patients with idiopathic pulmonary fibrosis (CAPACITY): two randomised trials. Lancet 2011;377:1760-1769.

2. Jiang $\mathrm{C}$, Huang $\mathrm{H}$, Liu J, Wang $\mathrm{Y}, \mathrm{Lu} Z$, Xu Z. Adverse events of pirfenidone for the treatment of pulmonary fibrosis: a meta-analysis of randomized controlled trials. PLoS One 2012;7:e47024.

3. Natkunarajah J, Stitson RN, Harland CC. A florid rash during summer. Photodistributed lichenoid drug eruption (LDE) secondary to quinine. Clin Exp Dermatol 2010; 35:e83-84.

4. Seto Y, Inoue R, Kato M, Yamada S, Onoue S. Photosafety assessments on pirfenidone: photochemical, photobiological, and pharmacokinetic characterization. J Photochem Photobiol B 2013;120:44-51.

5. Asarch A, Gottlieb AB, Lee J, Masterpol KS, Scheinman PL, Stadecker MJ, et al. Lichen planus-like eruptions: an emerging side effect of tumor necrosis factor-alpha antagonists. J Am Acad Dermatol 2009;61:104-111. 